\title{
ゴム混練中における加硫促進剤の熱履歴と その加硫挙動について(2)
}

\author{
〔チアゾール系加硫促進剂〕
}

インターナルミキサーによるゴムの混練りでは, 通常 ゴム温度は $100^{\circ} \mathrm{C}$ 以上の高温になるため, 加硫系薬剤 (硫黄, 加硫促進剤など）の配合は、ゴムコンパウンド をミキサーから一旦排出し, 十分冷却した後に, 再びミ キサー又はロールで配合する方法 (二段法)が一般に行わ れている，生産性を上げるために，一段法で加硫系薬剂 をすべて配合することが望まれているが，スコーチの危 険性から困難な場合が多い.しかし, 数種類の加硫促進 剤を再練り時に配合するのは煩わしいため, 加硫促進剤 は一段の段階で配合し，そのゴムコンパウンドを排出後 冷却し, 硫黄だけを再練り時に配合する方法もまれに行 われている.この方法は, 硫黄及び加硫促進剂を同時に 一段の段階で配合する場合に比べてスューチの危険性は 減るが, 硫黄不在下でも加硫促進剤は熱履歴を受けるた め, 変質, 分解などが起こり加硫挙動に変化が起こるこ とが考えられる.

前回は, スルフェンアミド系加硫促進剤(ノクセラー $\mathrm{CZ}, \mathrm{NS}, \mathrm{MSA}, \mathrm{DZ})$ につて, インターナルミキサーで ゴム混練中に, 熱履歴を受けた場合の加硫挙動の変化に ついて紹介した.

今回は, チアゾール系加硫促進剤のノクセラー $\mathbf{M}$, MZ, DM, M-60 の場合について紹介する. 配合手順に ついては前回と同様であり, $\mathrm{A}$ 方法から $\mathrm{E}$ 方法で実施
した(図 1 ，表 1 ). チアゾール系加硫促進剤では， $\mathrm{E}$ 方 法(一段法)で配合したゴムコンパウンドは，ミキサー中 で既にスコーチしてしまい，ダンプしたゴムコンパウン ドのムーニースコーチ測定は不可能であった。一方, $\mathrm{C}$ 方法で配合したゴムコンパウンドは, 加硫挙動(ムーニ ースコーチ試験, キュラストメータ加硫試験)に大きな 変化は認めず, 熱履歴（硫黄不在下に拈いて）を受けて もスルフェンアミド系の場合の様に大きな加硫挙動の変 化は認められない. 次回は, チアゾール系のノクセラー

64, MDB, DM+D, DM+H の場合について紹介する.

\section{実 験}

1. 配合 $\operatorname{SBR}(1712)$

137.5

ステアリン酸

1

$\mathrm{HAF}$ ブラック

60

酸化亜鉛

5

硫黄

2

加硫促進剂

1

\section{2. 配合手順}

バンバリー（ラボプラストミル75 cc）による混練プロ ファイルを図 1 に示す.

バンバリーからダンプしたゴムコンパウンド(約 $\left.145^{\circ} \mathrm{C}\right)$ を室温まで冷却し, その後残りの加硫系薬剤*1

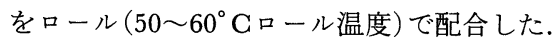

表 1

\begin{tabular}{|c|c|c|c|c|c|c|}
\hline 配合方法 & 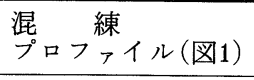 & 〔A 方法〕 & 〔B方法〕 & [C 方法] & [D方法] & 〔E方法〕 \\
\hline \multirow{2}{*}{ 配ンバリー } & [I]〔II]で投入 & $\left\{\begin{array}{l}\text { SBR } \\
\text { ステァリン酸 } \\
\text { HAF }\end{array}\right.$ & $\begin{array}{l}\text { SBR } \\
\text { ステアリン酸 } \\
\text { HAF }\end{array}$ & $\begin{array}{l}\text { SBR } \\
\text { ステアリン酸 } \\
\text { HAF }\end{array}$ & $\begin{array}{l}\text { SBR } \\
\text { ステアリン酸 } \\
\text { HAF }\end{array}$ & $\begin{array}{l}\text { SBR } \\
\text { ステァリン酸 } \\
\text { HAF }\end{array}$ \\
\hline & 〔III]で投入 & $\mathrm{ZnO}$ & $\begin{array}{l}\mathrm{ZnO} \\
\text { 硫黄 }\end{array}$ & $\begin{array}{l}\mathrm{ZnO} \\
\text { 加硫促進剤 }\end{array}$ & 加硫促進剤 & $\begin{array}{l}\mathrm{ZnO} \\
\text { 硫黄 } \\
\text { 加硫促進剤 }\end{array}$ \\
\hline ロール配合 & & $\begin{array}{l}\text { 硫黄 } \\
\text { 加硫促進剂 }\end{array}$ & 加硫促進剤 & 硫黄 & $\begin{array}{l}\text { 硫黄 } \\
\mathrm{ZnO}\end{array}$ & - \\
\hline
\end{tabular}

*1 酸化亜鉛, 硫黄, 加硫促進剤をさす 
紹 介

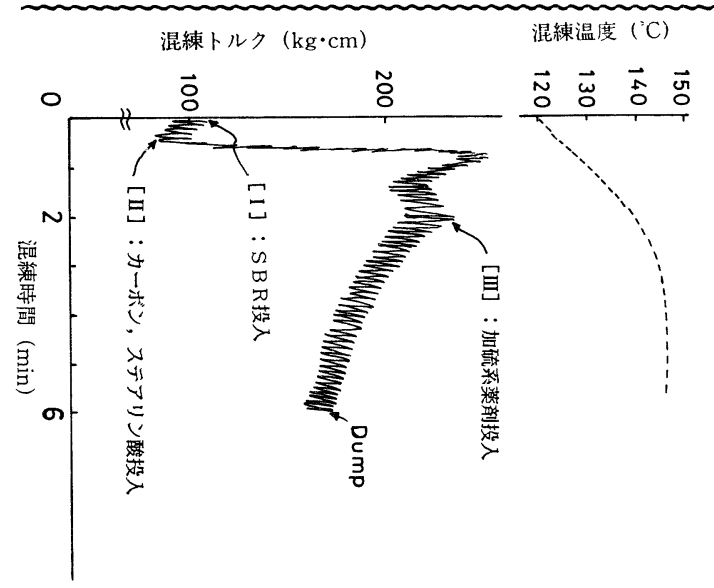

図1 混練プロファイル ラボプラストミル試験 機: バンバリー75cc型70 rpm

3. ムーニースコーチ試験

表 2 JIS K 6300に準拠, $\mathrm{ML}_{-1}\left(135^{\circ} \mathrm{C}\right)$

\begin{tabular}{|c|c|c|c|c|c|c|}
\hline \multirow{2}{*}{ 加 硫 } & & \multicolumn{5}{|c|}{ 配合方法 } \\
\hline & & [A] & {$[\mathrm{B}]$} & {$[\mathrm{C}]$} & {$[\mathrm{D}]$} & [E] \\
\hline \multirow{3}{*}{$\mathbf{M}$} & $\mathrm{V}_{\mathrm{m}}$ & 36 & 46 & 37 & 34 & \multirow{3}{*}{$\begin{array}{l}\text { 測定 } \\
\text { 不可 }\end{array}$} \\
\hline & $t_{5}$ & $17.4^{\prime}$ & $7.6^{\prime}$ & $16.2^{\prime}$ & $15.3^{\prime}$ & \\
\hline & $t_{35}$ & $23.5^{\prime}$ & $14.5^{\prime}$ & $23.1^{\prime}$ & $25.4^{\prime}$ & \\
\hline \multirow{3}{*}{$\mathbf{M Z}$} & $\mathrm{V}_{\mathrm{m}}$ & 36 & 48 & 37 & 34 & \multirow{3}{*}{$\begin{array}{l}\text { 測定 } \\
\text { 不可 }\end{array}$} \\
\hline & $t_{5}$ & $17.8^{\prime}$ & $7.0^{\prime}$ & $18.3^{\prime}$ & $16.0^{\prime}$ & \\
\hline & $t_{35}$ & $24.5^{\prime}$ & $13.2^{\prime}$ & $25.4^{\prime}$ & $27.1^{\prime}$ & \\
\hline \multirow{3}{*}{ DM } & $\mathrm{V}_{\mathrm{m}}$ & 36 & 45 & 36 & 33 & \multirow{3}{*}{$\begin{array}{l}\text { 測定 } \\
\text { 不可 }\end{array}$} \\
\hline & $t_{5}$ & $17.6^{\prime}$ & $10.5^{\prime}$ & $15.2^{\prime}$ & $15.4^{\prime}$ & \\
\hline & $t_{35}$ & $20.9^{\prime}$ & $14.2^{\prime}$ & $20.7^{\prime}$ & $22.5^{\prime}$ & \\
\hline \multirow{3}{*}{$M-60$} & $\mathrm{~V}_{\mathrm{m}}$ & 37 & 50 & 38 & 35 & \multirow{3}{*}{$\begin{array}{l}\text { 測定 } \\
\text { 不可 }\end{array}$} \\
\hline & $t_{5}$ & $8.1^{\prime}$ & $4.4^{\prime}$ & $9.1^{\prime}$ & $9.6^{\prime}$ & \\
\hline & $t_{35}$ & $9.8^{\prime}$ & $6.1^{\prime}$ & $11.5^{\prime}$ & $14.1^{\prime}$ & \\
\hline
\end{tabular}

4. キュラストメータ加硫試験

\begin{tabular}{|c|c|c|c|c|c|c|}
\hline \multirow{2}{*}{ 加 硫 } & & \multicolumn{5}{|c|}{ 配合方法 } \\
\hline & & [A] & [B] & {$[\mathrm{C}]$} & [D] & [E] \\
\hline \multirow{4}{*}{ M } & $\mathrm{M}_{\mathrm{L}}$ & 0.39 & 0.44 & 0.39 & 0.34 & 0.83 \\
\hline & $\mathrm{M}_{\mathrm{HF}}$ & 2.1 & 1.8 & 2.1 & 2.2 & 2.0 \\
\hline & $\mathrm{t}_{\mathrm{c}(10)}^{\prime}$ & $4.2^{\prime}$ & $3.0^{\prime}$ & $4.3^{\prime}$ & $4.5^{\prime}$ & $2.0^{\prime}$ \\
\hline & $t^{\prime}{ }_{c(90)}$ & $21.0^{\prime}$ & $22.5^{\prime}$ & $22.0^{\prime}$ & $19.5^{\prime}$ & $22.5^{\prime}$ \\
\hline \multirow{4}{*}{ MZ } & $\mathrm{M}_{\mathrm{L}}$ & 0.39 & 0.44 & 0.39 & 0.34 & 0.69 \\
\hline & $\mathrm{M}_{\mathrm{HF}}$ & 2.1 & 2.0 & 2.0 & 1.9 & 1.9 \\
\hline & $\mathbf{t}^{\prime}{ }_{c(10)}$ & $4.8^{\prime}$ & $2.8^{\prime}$ & $5.0^{\prime}$ & $4.2^{\prime}$ & $2.0^{\prime}$ \\
\hline & $t^{\prime}{ }_{c(90)}$ & $25.5^{\prime}$ & $20.0^{\prime}$ & $23.5^{\prime}$ & $26.5^{\prime}$ & $19.5^{\prime}$ \\
\hline \multirow{4}{*}{ DM } & $\mathrm{M}_{\mathrm{L}}$ & 0.39 & 0.44 & 0.39 & 0.34 & 0.69 \\
\hline & $\mathrm{M}_{\mathrm{HF}}$ & 2.1 & 2.1 & 2.0 & 1.9 & 2.0 \\
\hline & $\mathbf{t}_{\mathrm{c}(10)}^{\prime}$ & $3.7^{\prime}$ & $2.8^{\prime}$ & $4.0^{\prime}$ & $3.5^{\prime}$ & $1.5^{\prime}$ \\
\hline & $\mathbf{t}_{c(90)}^{\prime}$ & $21.0^{\prime}$ & $17.5^{\prime}$ & $23.0^{\prime}$ & $21.5^{\prime}$ & $20.0^{\prime}$ \\
\hline \multirow{4}{*}{$M-60$} & $\mathrm{M}_{\mathrm{L}}$ & 0.39 & 0.44 & 0.39 & 0.34 & 1.2 \\
\hline & $\mathbf{M}_{\mathrm{HF}}$ & 2.2 & 2.1 & 2.2 & 2.0 & 1.9 \\
\hline & $\mathbf{t}_{\mathrm{c}(10)}^{\prime}$ & $2.2^{\prime}$ & $1.4^{\prime}$ & $2.5^{\prime}$ & $2.8^{\prime}$ & $1.0^{\prime}$ \\
\hline & $\mathbf{t}^{\prime}{ }_{\mathrm{c}(90)}$ & $9.5^{\prime}$ & $8.5^{\prime}$ & $11.5^{\prime}$ & $13.5^{\prime}$ & $10.0^{\prime}$ \\
\hline
\end{tabular}

$\mathrm{M}_{\mathrm{L}}, \mathrm{M}_{\mathrm{HF}}$ の単位は $[\mathrm{N} \cdot \mathrm{m}]$
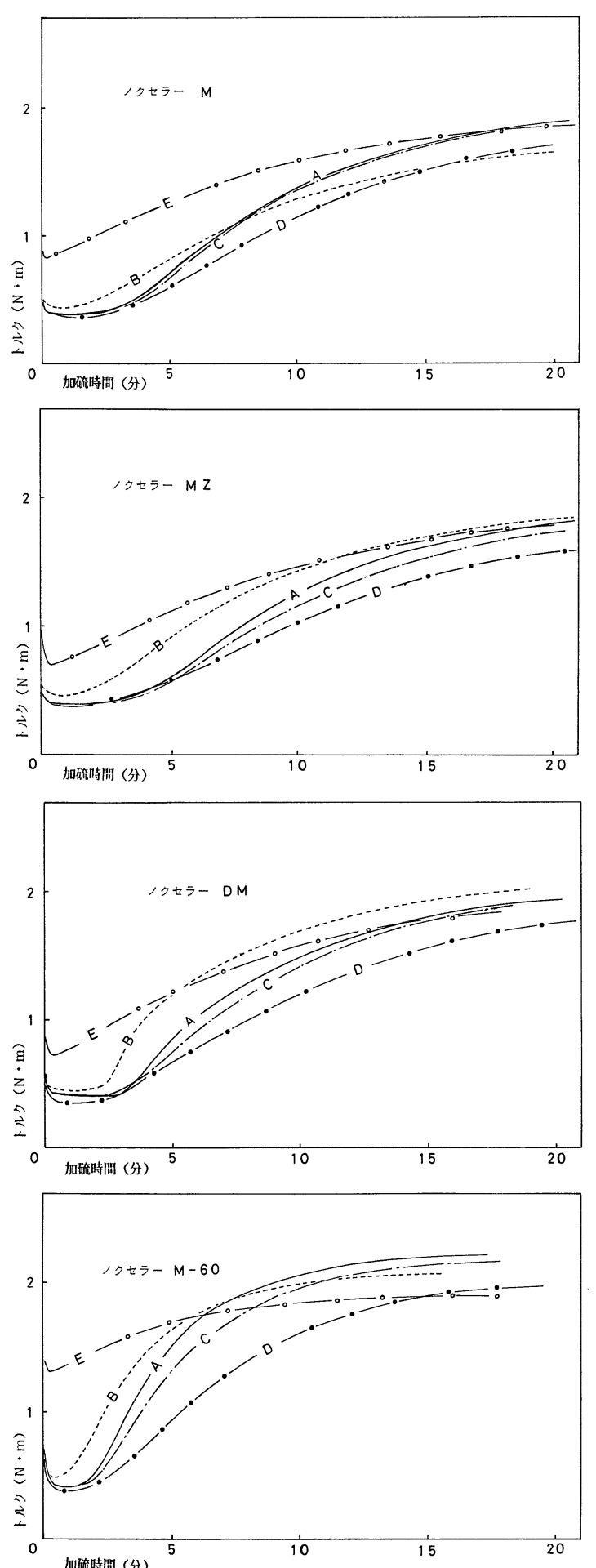

図 2 キュラストメータ加硫曲線図 $160^{\circ} \mathrm{C}$

大内新興化学工業株式会社 